\title{
UNIVERSITY OF LUND RADIOCARBON DATES XVIII
}

\author{
SÖREN HÅKANSSON
}

Radiocarbon Dating Laboratory, Department of Quaternary Geology University of Lund, Sweden

\section{INTRODUCTION}

Most of the ${ }^{14} \mathrm{C}$ measurements reported here were made between October 1983 and October 1984. Equipment, measurement, and treatment of samples are as reported previously $(\mathrm{R}, 1968$, v 10, p 36-37; 1976, v 18, p 290; 1980, v 22, p 1045).

Age calculations are based on a contemporary value equal to $95 \% 0$ of the activity of NBS oxalic acid standard (No. 4990A) and on the conventional half-life for ${ }^{14} \mathrm{C}$ of $5568 \mathrm{yr}$. Results are reported in years before 1950 (years BP). Errors quoted with the dates are based on counting statistics alone and are equivalent to \pm 1 standard deviation $( \pm \sigma)$.

Corrections for deviations from $\delta^{13} \mathrm{C}=-25.0 \%$ in the PDB scale are applied for all samples; also for marine shells. The apparent age for marine material due to the reservoir effect must be subtracted from our dates on such samples.

The remark "undersized; diluted," in Comments means the sample did not produce enough $\mathrm{CO}_{2}$ to fill the counter to normal pressure and "dead" $\mathrm{CO}_{2}$ from anthracite was introduced to make up the pressure. "\%o sample" indicates amount of $\mathrm{CO}_{2}$ derived from the sample present in the diluted counting gas; the rest is "dead" $\mathrm{CO}_{2}$. Organic carbon content reported for bone samples is calculated from yield of $\mathrm{CO}_{2}$ by combustion of gelatine remaining after treatment. Organic carbon lost during treatment is not included in calculated percentage.

The description of each sample is based on information provided by the submitter.

\section{ACKNOWLEDGMENTS}

The author thanks Kerstin Lundahl for sample preparation and routine operation of the dating equipment, and O Gustafsson, Dept Marine Geol, Univ Göteborg, for mass-spectrometric determination of $\delta^{13} \mathrm{C}$.

\section{GEOLOGIC SAMPLES}

Sweden

\section{Eastern Småland series}

Sediment and coarse organic matter $(>0.25 \mathrm{~mm})$ from lakes Bergakyllen $\left(57^{\circ} 11^{\prime} \mathrm{N}, 16^{\circ} 08^{\prime} \mathrm{E}\right)$, Skvarran $\left(57^{\circ} 12^{\prime} \mathrm{N}, 16^{\circ} 09^{\prime} \mathrm{E}\right)$, Stensjön ( $57^{\circ}$ $\left.12^{\prime} \mathrm{N}, 16^{\circ} 17^{\prime} \mathrm{E}\right)$, and Bastgöl ( $\left.57^{\circ} 13^{\prime} \mathrm{N}, 16^{\circ} 19^{\prime} \mathrm{E}\right)$, Kalmar län, E Småland. Coll March 1983 and subm by N-O Svensson, Dept Quaternary Geol, Univ Lund. Dated as part of study of Late Weichselian and Early Holocene shore displacement in E Småland. Depths refer to sediment surface. Samples 
were taken with Russian-type corer, diam $10 \mathrm{~cm}$. All samples pretreated with $\mathrm{HCl}$. Lu-2172 received additional treatment with $\mathrm{NaOH}$ and soluble fraction was dated separately.

\section{Bergakyllen}

\section{Lu-2171. Bergakyllen 1}

$10,620 \pm 130$

Coarse organic matter, mainly water moss, depth $675 \mathrm{~cm}$, just above isolation level. Comment: sample undersized; diluted; 52\%0 sample. (3 1-day counts.)

\section{Lu-2172. Bergakyllen 4, insoluble}

Insoluble fraction of muddy clay, $<0.3 \mathrm{~mm}$, depth $675 \mathrm{~cm}$.

Lu-2172A. Bergakyllen 4, soluble

$11,260 \pm 100$

Acid-precipitated part of $\mathrm{NaOH}$-soluble fraction, depth $675 \mathrm{~cm}$.

$$
\begin{array}{r}
11,360 \pm 100 \\
\delta^{13} C=-26.1 \% 0
\end{array}
$$

\section{Lu-2173. Bergakyllen 2}

$10,460 \pm 90$

Clay gyttja, depth $665 \mathrm{~cm}$.

Lu-2174. Bergakyllen 3 $\delta^{13} C=-27.0 \%$

Clay gyttja, depth $645 \mathrm{~cm}$.

\section{Skvarran}

\section{Lu-2175. Skvarran 1}

$11,610 \pm 100$

Clay gyttja, depth $438 \mathrm{~cm}$, just above isolation level.

\section{Lu-2176. Skvarran 2}

$$
\begin{array}{r}
\mathbf{9 7 1 0} \pm \mathbf{9 0} \\
\delta^{13} C=-26.5 \% 0
\end{array}
$$

Clay gyttja, depth $426 \mathrm{~cm}$, ca $15 \mathrm{~cm}$ above isolation level.

\section{Lu-2177. Skvarran 4}

$$
\delta^{13} C=-21.1 \%
$$

Clay gyttja, depth $409 \mathrm{~cm}$, ca $30 \mathrm{~cm}$ above isolation level.

\section{Stensjön}

Lu-2178. Stensjön 1

$10,720 \pm 100$

Clay gyttja, depth $437 \mathrm{~cm}$, just above isolation level.

$$
10,920 \pm 100
$$$$
\delta^{13} C=-23.0 \%
$$

$$
\begin{array}{r}
10,150 \pm 90 \\
\delta^{13} C=-22.6 \% o
\end{array}
$$

$\delta^{13} C=-24.0 \%$ 
Lu-2179. Stensjön 2

$9850 \pm 90$

Muddy clay, depth $433 \mathrm{~cm}$. Comment: no clear indication of carbonate in this sample.

Bastgöl

Lu-2180. Bastgöl 1

Clay gyttja, depth $387 \mathrm{~cm}$.

Lu-2181. Bastgöl 2 sion level. Comment: no clear indication of carbonate in this sample.

General Comment: acid treatment revealed carbonate in most samples.

Lu-2210. Dösebacka 1983

$\mathbf{9 8 4 0} \pm \mathbf{9 0}$
$\delta^{13} C=-24.1 \%$ o

$9610 \pm 90$

$\delta^{13} C=-25.3 \%$

Silt with $1.4 \%$ organic carbon content from lens-shaped deposit, $75 \mathrm{~cm}$ thick, overlain by glaciofluvial material A4 (Hillefors, 1969, p 40-52) and underlain by till ("Mammoth level") at Dösebacka gravel pit ( $55^{\circ} 37^{\prime} \mathrm{N}$, $\left.13^{\circ} 04^{\prime} \mathrm{E}\right), 3 \mathrm{~km}$ NNE of Kungälv, Bohuslän. Coll Aug 1983 and subm by $\AA$ Hillefors, Dept Phys Geog, Univ Göteborg. Comment: no pretreatment. (4 1-day counts.)

\section{Central Halland Series I}

Sediment, water moss, and mollusk and barnacle shells from lakes Valingesjön ( $\left.57^{\circ} 10^{\prime} 30^{\prime \prime} \mathrm{N}, 12^{\circ} 23^{\prime} 45^{\prime \prime} \mathrm{E}\right)$, alt $30 \mathrm{~m}$, Kalvsjön $\left(57^{\circ} 05^{\prime} 30^{\prime \prime} \mathrm{N}, 12^{\circ}\right.$ $\left.32^{\prime} 30^{\prime \prime} \mathrm{E}\right)$, alt $63 \mathrm{~m}$, Lillsjön $\left(57^{\circ} 05^{\prime} 20^{\prime \prime} \mathrm{N}, 12^{\circ} 31^{\prime} 40^{\prime \prime} \mathrm{E}\right)$, alt $80 \mathrm{~m}$, and Grimsjön ( $\left.57^{\circ} 06^{\prime} 45^{\prime \prime} \mathrm{N}, 12^{\circ} 28^{\prime} 30^{\prime \prime} \mathrm{E}\right)$, alt $56 \mathrm{~m}$, Central Halland. Coll Feb 1983 and Feb 1984 (Valingesjön) and subm by S Björck and G Digerfeldt, Dept Quaternary Geol, Univ Lund. Dating is part of study of Late Weichselian biostratigraphy, magnetostratigraphy, and relative sea-level changes at Swedish coast. Sediment samples were taken with Livingstone sampler, diam $10 \mathrm{~cm}$. Moss and mollusk and barnacle shells were washed from same level of several sediment cores from each sampling point. Depths refer to sediment surface. Chronozones are according to Mangerud et al (1974).

\section{Valingesjön}

Water depth $1.8 \mathrm{~m}$ at sampling point.

\section{Lu-2343. Valingesjön 1, 1620 to $1760 \mathrm{~cm}$}

$$
13,150 \pm 120
$$

Small shells and fragments (Hiatella arctica, Mytilus edulis, Balanus balanus, Macoma calcarea, and Portlandia arctica) from sandy, silty clay. B $\phi l l i n g$ chronozone. Comment: outer 12\%0 removed by acid leaching. Sample undersized; diluted, 78\% sample. (3 1-day counts.) 


\section{Lu-2344. Valingesjön 2, 1445 to $1520 \mathrm{~cm}$}

$12,680 \pm 110$

Small shells and fragments (Mytilus edulis, Balanus balanus, Hiatella arctica, and Portlandia arctica) from silty clay. B $\phi$ lling chronozone. Comment: outer $30 \%$ removed by acid leaching.

\section{Kalvsjön}

Water depth $3.3 \mathrm{~m}$ at sampling point.

\section{Lu-2246. Kalvsjön, 231 to $233 \mathrm{~cm}$}

$12,210 \pm 320$

$\delta^{13} C=-30.9 \%$

Water moss from sediment, transition Older Dryas/Aller $\phi \mathrm{d}$ chronozone. Comment: no pretreatment; small sample; diluted; $15 \%$ sample. (6 1-day counts.) Burned at $<650^{\circ} \mathrm{C}$ to avoid pyrolysis of carbonates that may be present in untreated samples.

\section{Lu-2247. Kalvsjön, 220 to $222 \mathrm{~cm}$}

$11,070 \pm 250$

Water moss from sediment, Aller $\phi \mathrm{d}$ chronozone. Comment: no pretreatment; small sample; diluted; $18 \%$ sample. (5 1-day counts.) Burned at $<650^{\circ} \mathrm{C}$.

\section{Lillsjön} $\mathrm{HCl}$.

Water depth $450 \mathrm{~cm}$ at sampling point. All samples pretreated with

\section{Lu-2236. Lillsjön, 425 to $430 \mathrm{~cm}$}

$12,000 \pm 100$

Muddy clay. Comment: sample undersized; diluted; $73 \%$ sample. (3 1-day counts.)

\section{Lu-2238. Lillsjön, 416 to $421 \mathrm{~cm}$}

$11,880 \pm 120$

Clay gyttja. Comment: sample undersized; diluted; $86 \%$ sample.

\section{Lu-2237. Lillsjön, 406.5 to $411.5 \mathrm{~cm}$}

$10,930 \pm 100$

Clay gyttja.

\section{Grimsjön}

Water depth $330 \mathrm{~cm}$ at sampling point.

\section{Lu-2245. Grimsjön, 233 to $237 \mathrm{~cm}$}

$12,490 \pm 190$

$\delta^{13} \mathrm{C}=-31.7 \%$

Water moss, probably Older Dryas/B $\phi$ lling chronozone. Comment: no pretreatment; small sample; diluted; $40 \%$ sample. (3 1-day counts.) Burned at $<600^{\circ} \mathrm{C}$ to avoid pyrolysis of carbonates that may be present in untreated samples. 
Lu-2266. Halsjön 8

$9800 \pm 230$

$\delta^{13} C=-27.7 \%$

Water moss washed from sediment from Lake Halsjön $\left(56^{\circ} 14^{\prime} \mathrm{N}, 15^{\circ}\right.$ $\left.19^{\prime} \mathrm{E}\right)$, central Blekinge. Sample from top of Layer 1 in Core I, ca $4.8 \mathrm{~m}$ below mire surface, corresponding to Layer 2 in Core II (Björck, 1979, p $80-88 ; 1981$, p 33). Coll Aug 1983 and subm by S Björck. Dated as complement to previous dates from Halsjön (R, 1980, v 22, p 1049). Comment: no pretreatment; sample undersized; diluted; $22 \%$ sample. (3 1-day counts.)

\section{Vasasjön series}

Peat and gyttja from ancient Vasasjön, ca $4 \mathrm{~km}$ N of Sövestad, S Scania $\left(55^{\circ} 32.2^{\prime} \mathrm{N}, 13^{\circ} 48.3^{\prime} \mathrm{E}\right)$. Coll 1983 and subm by M Hjelmroos, Dept Quaternary Geol, Univ Lund. Dated as part of study of local vegetational changes during last $6000 \mathrm{yr}$ in Ystad area. For other dates from same site, see R, 1983, v 25, p 880 (Baldringe series). Depths given are below present surface.

Lu-2282. Vasasjön 1, 254 to $259 \mathrm{~cm}$

$3860 \pm 60$

$\delta^{13} C=-29.8 \%$ o

Highly humified brushwood peat. Fagus pollen percentage decreasing. Comment: pretreated with $\mathrm{HCl}$.

\section{Lu-2283. Vasasjön 2, 338 to $343 \mathrm{~cm}$}

$3640 \pm 60$

Moderately humified brushwood peat. Increase of Fagus and cereal pollen percentages. Comment: pretreated with $\mathrm{HCl}$ and $\mathrm{NaOH}$; charred in nitrogen atmosphere before burning.

\section{Lu-2284. Vasasjön 3, 469 to $471 \mathrm{~cm}$}

$5270 \pm 60$

Gyttja. Decrease of Ulmus pollen percentage. Comment: pretreated with HCl.

\section{Dags Mosse Series III}

Peat from S part of mosse, SW of Lake Tåkern, Östergötland $\left(58^{\circ} 19.5^{\prime}\right.$ $\mathrm{N}, 14^{\circ} 42^{\prime} \mathrm{E}$ ). Coll May 1982 by $\mathrm{H}$ Göransson and $\mathrm{T}$ Persson; subm by $\mathrm{H}$ Göransson, Dept Quaternary Geol, Univ Lund. Dated as complement to Dags Mosse Series I and II (R, 1983, v 25, p 877-880; 1984, v 26, p 393394). Depths refer to present bog surface. All samples pretreated with $\mathrm{HCl}$ and charred in nitrogen atmosphere before burning. Pollen zones according to Göransson (1977, p 36-43).

\section{Lu-2336. Dags Mosse, 425 to $430 \mathrm{~cm}$}

$6840 \pm 70$

$\delta^{13} C=-29.4 \%$

Muddy Phragmites peat. Tilia-Quercus-Ulmus sub-zone of QuercusPinus pollen assemblage zone (Atlantic time). 
Lu-2337. Dags Mosse, 400 to $405 \mathrm{~cm}$ $6380 \pm 70$

Muddy Phragmites peat. Same pollen sub-zone as Lu-2336, above.

Lu-2370. Dags Mosse, 380 to $385 \mathrm{~cm}$ $6350 \pm 70$

Radicel (Thelypteris-Phragmites) peat. Sam and -2337 .

\section{Lu-2369. Dags Mosse, 360 to $365 \mathrm{~cm}$}

$6210 \pm 70$

Radicel peat. Same pollen sub-zone as preceding samples.

Lu-2368. Dags Mosse, 340 to $345 \mathrm{~cm}$

$5950 \pm 70$

Radicel peat. Same pollen sub-zone as preceding samples.

Lu-2367. Dags Mosse, 320 to $325 \mathrm{~cm}$

$5750 \pm 70$

Radicel peat. Same pollen sub-zone as preceding samples.

Lu-2366. Dags Mosse, 300 to $305 \mathrm{~cm}$

$5340 \pm 60$

Radicel peat. Same pollen sub-zone as preceding samples.

Lu-2278. Dags Mosse, 280 to $287 \mathrm{~cm}$

$\mathbf{3 7 1 0} \pm \mathbf{6 0}$

$\delta^{13} \mathrm{C}=-27.8 \%$

Sphagnum peat from very end of Quercus-Tilia-Ulmus sub-zone of Quercus-Pinus pollen assemblage zone.

Lu-2279. Dags Mosse, 266 to $274 \mathrm{~cm}$

$3360 \pm 60$

Sphagnum peat. Transition Quercus-Tilia-Ulmus/ Quercus-Tilia subzones.

Lu-2267. Dags Mosse, 244 to $247 \mathrm{~cm}$

$\mathbf{3 1 8 0} \pm \mathbf{5 0}$

Sphagnum peat. Almost same pollen spectrum as for Lu-2279, above.

Lu-2268. Dags Mosse, 233.5 to $236.5 \mathrm{~cm}$

$\mathbf{2 8 3 0} \pm \mathbf{5 0}$

Sphagnum peat. Quercus-Tilia sub-zone of Quercus-Pinus pollen assemblage zone.

Lu-2269. Dags Mosse, 223.5 to $226.5 \mathrm{~cm}$

$\mathbf{2 7 8 0} \pm \mathbf{5 0}$

Sphagne $\quad \delta^{13} C=-27.1 \%$ pollen percentage of Fraxinus; Carpinus $0.5 \%$ 
Lu-2270. Dags Mosse, 218.5 to $221.5 \mathrm{~cm}$

Sphagnum peat. Same pollen sub-zone as Lu-2268, above.

Lu-2271. Dags Mosse, 208.5 to $211.5 \mathrm{~cm}$

$2380 \pm 60$

Sphagnum peat. Fraxinus pollen $1.1 \%$.

$\delta^{13} C=-26.4 \%$

Lu-2272. Dags Mosse, 203.5 to $206.5 \mathrm{~cm}$

$2290 \pm 50$

Sphagnum peat. Upper part of Quercus-Tilia sub-zone of Quercus-Pinus pollen assemblage zone. Fraxinus pollen 1.1\%

\section{Lu-2273. Dags Mosse, 198.5 to $201.5 \mathrm{~cm}$ \\ $2220 \pm 50$}

Sphagnum peat. Uppermost part of Quercus-Pinus pollen assemblage zone. Decrease of Quercetum Mixtum pollen percentage; Picea pollen increasing to $0.4 \%$.

\section{I.u-2274. Dags Mosse, 193.5 to $196.5 \mathrm{~cm}$}

$\mathbf{2 0 0 0} \pm \mathbf{5 0}$

Sphagnum-Eriophorum vaginatum peat. Transition Quercus-Pinus/Picea pollen assemblage zone. Rational Picea limit. High percentage of Plantago lanceolata pollen.

\section{Lu-2275. Dags Mosse, 188.5 to $191.5 \mathrm{~cm}$}

$1900 \pm 50$

Sphagnum-Eriophorum vaginatum peat. Lowermost part of Picea pollen assemblage zone. Picea pollen percentage increasing to $2 \%$. Carpinus increasing to $1.6 \%$.

\section{Lu-2276. Dags Mosse, 178.5 to $181.5 \mathrm{~cm}$}

$$
\mathbf{1 6 7 0} \pm \mathbf{5 0}
$$

Eriophorum vaginatum peat. Lower part of Picea pollen assemblage zone. Picea pollen 3.2\% pollen.

\section{Lu-2277. Dags Mosse, 175 to $177 \mathrm{~cm}$}

$1600 \pm 50$

Eriophorum vaginatum peat. Picea-Quercus sub-zone of Picea pollen assemblage zone. Increase of Rumex acetosella pollen percentage; 1 st find of Secale pollen.

Lu-2288. Dags Mosse, 171.5 to $178.5 \mathrm{~cm}$

$1540 \pm 45$

Sphagnum peat. Picea pollen assemblage zone. 
Lu-2355. Dags Mosse, 164 to $171 \mathrm{~cm}$

Sphagnum peat. Picea pollen assemblage zone.

Lu-2289. Dags Mosse, 156.5 to $163.5 \mathrm{~cm}$

Sphagnum peat. Increase of Betula and decrease of Pinus pollen percentages. Two pollen grains of Secale. Comment: sample undersized; diluted; $47 \%$ sample.

\section{Lu-2290. Dags Mosse, 146.5 to $153.5 \mathrm{~cm}$}

Sphagnum peat. Beginning decrease of Alnus pollen percentage.

\section{Lu-2291. Dags Mosse, 140 to $145 \mathrm{~cm}$}

$$
\delta^{13} C=\begin{aligned}
& 990 \pm 60 \\
& -26.6 \%
\end{aligned}
$$

Sphagnum peat. Continuing decrease of Alnus pollen percentage; max of Picea pollen (10.6\%). Comment: sample undersized; diluted; $62 \%$ sample.

\section{Lu-2292. Dags Mosse, 131.5 to $138.5 \mathrm{~cm}$}

$\delta^{13} C=-26.3 \%$

Sphagnum peat. Absolute min in Alnus pollen curve. Comment: sample undersized; diluted; 77\% sample.

Lu-2293. Dags Mosse, 121.5 to $128.5 \mathrm{~cm}$

$990 \pm 45$

$$
\delta^{13} C=-26.6 \%
$$

Sphagnum peat. Increase of Alnus pollen percentage; max in pollen curves for Betula and Tilia.

\section{Lu-2294. Dags Mosse, 101.5 to $108.5 \mathrm{~cm}$}

$$
\mathbf{8 2 0} \pm \mathbf{5 0}
$$

Sphagnum peat. Beginning of Cannabaceae pollen curve. Comment: sample undersized; diluted; $83 \%$ sample.

\section{Lu-2295. Dags Mosse, 94 to $101.5 \mathrm{~cm}$}

Sphagnum peat. Comment: sample undersized; diluted; $56 \%$ sample.

\section{Lu-2356. Dags Mosse, 93 to $95 \mathrm{~cm}$}

Sphagnum peat. Upper part of Picea-Quercus sub-zone of Picea pollen assemblage zone.

\section{Övre Örevattnet series}

Sediment from Övre Örevattnet, $6.5 \mathrm{~km}$ ESE of Hålanda, Västergötland $\left(58^{\circ} 02^{\prime} \mathrm{N}, 12^{\circ} 24^{\prime} \mathrm{E}\right)$, alt $145 \mathrm{~m}$. Coll Feb 1983 by K Svedhage, Dept Geol, Univ Göteborg; subm by S Björck. Dated as part of study of Late 
Weichselian shore displacement in Västergötland. Sediment core taken with Russian sampler. All samples except Lu-2360 and -2361 undersized; diluted. Amount of $\mathrm{CO}_{2}$ from sample is given in Comments as "\%o sample." All samples pretreated with $\mathrm{HCl}$. Depths refer to sediment surface.

\section{Lu-2264. Övre Örevattnet 2}

$11,940 \pm 140$

Muddy clay, 327 to $332 \mathrm{~cm}$. Max in Empetrum pollen curve. Comment: $71 \% 0$ sample.

\section{Lu-2358. Övre Örevattnet 3}

$11,440 \pm 150$ $\delta^{13} C=-25.4 \%$

Muddy clay, 324 to $327 \mathrm{~cm}$. Artemisia pollen percentage increasing. Comment: $58 \%$ sample.

\section{Lu-2359. Övre Örevattnet 4}

$10,890 \pm 130$

Clay gyttja, 317 to $320 \mathrm{~cm}$. Max in Artemisia pollen curve. Comment: 68 $\%$ sample.

\section{Lu-2265. Övre Örevattnet 5}

$10,240 \pm 110$

Clay gyttja, 310 to $313 \mathrm{~cm}$. Empetrum pollen percentage increasing. Comment: $76 \%$ sample.

\section{Lu-2360. Övre Örevattnet 6}

$9880 \pm 100$

Gyttja, 305 to $308 \mathrm{~cm}$. Max in Juniperus pollen curve.

\section{Lu-2361. Övre Örevattnet 7}

$9230 \pm 90$

$\delta^{13} \mathrm{C}=-28.5 \%$ $\left(\mathrm{C}^{\circ}\right)$.

Gyttja, 295 to $298 \mathrm{~cm}$. Beginning of continuous Corylus pollen curve

\section{Lu-2362. Övre Örevattnet 8}

$8550 \pm 120$

Gyttja, 267 to $270 \mathrm{~cm}$. Beginning of continuous Alnus pollen curve $\left(\mathrm{A}^{\circ}\right)$. Comment: $92 \%$ sample.

\section{Store mosse series}

Peat, Småland ( $\left.57^{\circ} 14^{\prime} 30^{\prime \prime} \mathrm{N}, 13^{\circ} 56^{\prime} \mathrm{E}\right)$. Coll 1982 and 1983 and subm by Göran Svensson, Dept Plant Ecol, Univ Lund. Results of study of recent vegetation at Store mosse pub by Svensson (1965). Dating is part of study of Holocene development of bog vegetation in area. Samples pooled from corresponding levels in 2 cores from each coring point taken with Russian sampler. Depths given below refer to bog surface. Degree of humification is given in scale from $\mathrm{H} 1$ (no humification) to $\mathrm{H} 10$ (almost completely humified). All samples pretreated with $\mathrm{HCl}$ and charred in nitrogen atmosphere before burning. 
Lu-2308. Store mosse 1,148 to $150 \mathrm{~cm}$ $\mathbf{2 3 4 0} \pm \mathbf{5 0}$

Sphagnum peat, H 7, Coring Point 9:82. Sample taken $4 \mathrm{~cm}$ above highly humified brushwood peat.

\section{Lu-2309. Store mosse 2,165 to $168 \mathrm{~cm}$}

$\mathbf{7 7 0} \pm \mathbf{4 5}$

Sphagnum peat, H 3, Coring Point 7:82. Sample taken $4 \mathrm{~cm}$ above transition Carex-Sphagnum/Sphagnum peat.

Lu-2310. Store mosse 3, 280 to $283 \mathrm{~cm}$

$\mathbf{2 3 1 0} \pm \mathbf{5 0}$

Sphagnum peat, $\mathrm{H}$ 6, Coring Point 7:82. Sample taken $5 \mathrm{~cm}$ above $1 \%$ sition brushwood/Sphagnum peat.

\section{Lu-2311. Store mosse 4,340 to $343 \mathrm{~cm}$}

$3900 \pm 60$

Sphagnum peat, H 7 to 8, Coring Point St 1.

$$
\delta^{13} C=-27.1 \%
$$

Lu-2312. Store mosse 5, 179 to $183 \mathrm{~cm}$

$1170 \pm 45$

Sphagnum peat, $\mathrm{H} \mathrm{4}$, Coring Point 5:82. Sample taken $1 \mathrm{~cm}$ above highly humified peat layer.

Lu-2313. Store mosse 6, 205 to $208 \mathrm{~cm}$

$1390 \pm 45$

Sphagnum peat (S cuspidatum), H 5 to 6 , Coring Point 5:82. Sample taken $22 \mathrm{~cm}$ below highly humified peat layer.

Lu-2314. Store mosse 7, 280 to $283 \mathrm{~cm}$

Sphagnum peat, H 4, Coring Point 5:82.

$2430 \pm 50$

$\delta^{13} C=-26.9 \%$

Lu-2315. Store mosse 8,372 to $374 \mathrm{~cm}$

$2800 \pm 60$

Sphagnum peat, H 3 to 4, Coring Point 5:82. Sample taken $1 \mathrm{~cm}$ above brushwood peat with abundant Eriophorum vaginatum fibers.

\section{Lu-2316. Store mosse 9, 108 to $114 \mathrm{~cm}$}

$240 \pm 45$

Sphagnum peat, 4 2, Coring Point 24:82. Sample underain by brushwood peat rich in Eriophorum vaginatum fibers.

\section{Lu-2317. Store mosse 10,152 to $155 \mathrm{~cm}$

$$
\mathbf{8 1 0} \pm \mathbf{5 0}
$$$$
\delta^{13} C=-26.8 \%
$$

Sphagnum peat (S magellanicum), H 3, Coring Point 22:82. Sample taken $1 \mathrm{~cm}$ above highly humified peat layer with Eriophorum vaginatum. Comment: sample undersized; diluted; $85 \% 0$ sample. 
Lu-2318. Store mosse 11,175 to $178 \mathrm{~cm}$

Sphagnum peat, $\mathrm{H} 7$ to 8 , Coring Point 18:82. Sample taken $1 \mathrm{~cm}$ above very highly humified peat layer.

Lu-2319. Store mosse 12,515 to $518 \mathrm{~cm}$

$6830 \pm 70$

Sphagnum peat, H 6, Coring Point Bj:83.

$\delta^{13} C=-26.2 \% 0$

\section{Southern Baltic series}

Wood from 2 firmly rooted tree stumps from bottom of S Baltic Sea at water depth 13 to $14 \mathrm{~m}, 3.5 \mathrm{~km} \mathrm{~N}$ of Vitemölla $\left(55^{\circ} 43.9^{\prime} \mathrm{N}, 14^{\circ} 12.5^{\prime} \mathrm{E}\right)$. Coll May 1983 by L Hansen and Malmö Sport Diving Club; subm by T Persson, Dept Quaternary Geol, Univ Lund. Peat samples for pollen analysis were taken beneath one stump (Lu-2341) and at 3 nearby points. For other dates from S Baltic, see R, 1982, v 24, p 197-198. Pretreated with $\mathrm{HCl}$ and $\mathrm{NaOH}$.

Lu-2341. Southern Baltic 9

$9450 \pm 90$

Wood from ca 40 thin outer tree rings of stump with 95 to 100 tree rings. Wood Sample No. 1, Proj Lövdalen.

\section{Lu-2342. Southern Baltic 10}

$9590 \pm 90$

$\delta^{13} C=-26.6 \%$

Wood from ca 25 tree rings of stump with 90 to 100 remaining tree rings. Outermost ca 20 rings were ill-preserved and were removed before wood was taken for dating. Wood Sample No. 2, Proj Lövdalen.

\section{Lu-2297. Flohus 1}

$290 \pm 70$

$\delta^{13} C=-26.4 \% 0$

Wood chips, bark fragments, and seeds from clayey sediment ca $3 \mathrm{~m}$ below present surface, underlain by sandy gravel and overlain by sand, $\mathrm{W}$ of Västra Sönnarslöv, $\left(56^{\circ} 05^{\prime} \mathrm{N}, 13^{\circ} 05^{\prime} \mathrm{E}\right)$, NW Scania, alt ca $50 \mathrm{~m}$. Coll May 1983 and subm by G Lemdahl, Dept Quaternary Geol, Univ Lund. Pretreated with $\mathrm{HCl}$ and $\mathrm{NaOH}$. Comment: dated material apparently not in primary position. (1-day count.)

\section{Lu-2307. Holmby}

$420 \pm 45$

$\delta^{13} C=-25.8 \%$

Large charcoal pieces (Salix or Populus) id by T Bartholin, from charcoal layer in aeolian sand in gravel pit $500 \mathrm{~m} \mathrm{E}$ of Holmby church, Scania $\left(55^{\circ} 44^{\prime} 55^{\prime \prime} \mathrm{N}, 13^{\circ} 24^{\prime} 45^{\prime \prime} \mathrm{E}\right)$. Charcoal layer 120 to $128 \mathrm{~cm}$ below present surface, 2 to $10 \mathrm{~cm}$ above fossil ground surface, and underlain by aeolian sand. Coll Jan 1984 and subm by R Åhman, Dept Phys Geog, Univ Lund. Pretreated with $\mathrm{HCl}$ and $\mathrm{NaOH}$. 


\section{Icelandic Subfossil Marine Shell Series III}

Marine bivalve and balanid shells from SW Iceland. Coll 1983 by O Ingolfsson; subm by C Hjort, Dept Quaternary Geol, Univ Lund. Dated as complement to Icelandic Subfossil Marine Shell Series I and II (R, 1983, v 25, p 882; 1984, v 26, p 398-399).

\section{Lu-2338. Heynes 1}

$$
11,430 \pm 140
$$

Shells (Hiatella arctica, Macoma calcarea, Balanus balanus) from lowest part of silt layer, +2 to $3 \mathrm{~m}$, overlaying bedrock with glacial striation at Heynes, N shore of Hvalfjördur, SW Iceland $\left(64^{\circ} 18^{\prime} \mathrm{N}, 22^{\circ} 00^{\prime} \mathrm{W}\right)$. Comment: outer $8 \%$ removed by acid leaching. Sample undersized; diluted; 65 $\%$ sample.

\section{Lu-2339. Gröf 2}

$$
12,840 \pm 110
$$

Large shall fragments (Hiatella arciica) from silt, ca $+5 \mathrm{~m}$, overlain by delta sediment and till at Gröf, N shore of Hvalfjördur, SW Iceland $\left(64^{\circ} 20^{\prime}\right.$ $\left.\mathrm{N}, 21^{\circ} 50^{\prime} \mathrm{W}\right)$. Comment: outer $44 \%$ removed by acid leaching.

\section{Lu-2340. Arkarlakur 1}

$11,350 \pm 100$

Shells and fragments (Hiatella arctica, Mya truncata, Macoma calcarea) from till, ca $+3 \mathrm{~m}$, at Arkarlakur, Leiruvogur, $\mathrm{N}$ of Akrafjeld, SW Iceland $\left(64^{\circ} 22^{\prime} \mathrm{N}, 21^{\circ} 55^{\prime} \mathrm{W}\right)$. Comment: outer $22 \%$ removed by acid leaching.

General Comment: corrections for deviations from $\delta^{13} \mathrm{C}=-25 \%$ PDB are applied. No corrections are made for reservoir age of living marine mollusks. Reservoir age for waters of Iceland pub by Håkansson (1983b).

Switzerland

\section{Lu-2332. Blécheins}

Wood from outer ca 30 tree rings from piece of wood from glacial deposit $S$ of Geneva ( $\left.46^{\circ} 07^{\prime} 01^{\prime \prime} \mathrm{N}, 6^{\circ} 07^{\prime} 32^{\prime \prime} \mathrm{E}\right)$. Coll 1984 and subm by $\mathrm{G}$ Amberger, Service cantonal géol, Geneva. Comment: pretreated with $\mathrm{HCl}$ and $\mathrm{NaOH}$.

\section{Poland}

\section{Lu-2296. Suszek bog}

$11,810 \pm 140$

$\delta^{13} C=-27.8 \%$ o

Drift peat from basal layer in kettle basin, $12.7 \mathrm{~m}$ below bog surface, overlain by gyttja and peat, $\mathrm{E}$ of Chojnice $\left(53^{\circ} 43^{\prime} \mathrm{N}, 17^{\circ} 46.5^{\prime} \mathrm{E}\right)$. Coll Sept 1983 by $\mathrm{G}$ Miotk and B Adamczak; subm by M Adamczak, Biol Inst, Univ Torun. Comment: no pretreatment; sample undersized; diluted; $69 \%$ sample. 
Czechoslovakia

\section{Bobrov series (II)}

Peat and mud from calcitrophic spring mire, $2 \mathrm{~km}$ NE of Bobrov village near Dolný Kubín, NE Czechoslovakia (49 $27^{\prime}$ N, $19^{\circ} 34^{\prime}$ E). Coll Sept 1971 by $\mathbf{E}$ and K Rybníček; subm by E Rybníčková, Bot Inst, Czechoslovak Acad Sci, Brno. Dated as complement to Bobrov series (R, 1982, v 24, p 200201). All samples pretreated with $\mathrm{HCl}$. Depths refer to present bog surface. Pollen zones after Firbas (1949).

Lu-2219. Bobrov OK-1-B, 209 to $213 \mathrm{~cm}$

$10,150 \pm 90$

$\delta^{13} C=-23.8 \%$

Fen-mud with high content of clay and sand. End of Younger Dryas and beginning of Pre-boreal.

\section{Lu-2220. Bobrov OK-1-B, 65 to $70 \mathrm{~cm}$}

$6450 \pm 70$

Fen-peat. Late part of Pollen Zone AT VII.

\section{Lu-2221. Bobrov OK-1-B, $45 \mathrm{~cm}$}

$2650 \pm 50$

Fen-peat with small Ca content. Transition SB VIII/SA IX.

\section{Lu-2222. Bobrov OK-1-B, 21 to $23 \mathrm{~cm}$}

$360 \pm 45$

Fen-peat. Beginning of Pollen Zone SA X. Comment: sample probably contaminated by recent roots or humic material.

\section{Lu-2285. “Sivárňa”}

$11,340 \pm 100$

Peat with seeds of Pinus cembra from bog at "Sivárňa" near village Vyšné Ružbachy, Slovakia $\left(49^{\circ} 20^{\prime} \mathrm{N}, 20^{\circ} 36^{\prime} \mathrm{E}\right)$, alt ca $600 \mathrm{~m}$. Coll Oct 1983 and subm by V Jankovska, Ústav experimentální fytotech, Československá akad věd, Brno. Important for study of late-glacial distribution of Pinus cembra and reconstruction of forestation of Carpathian Basins at end of glacial period. Pretreated with $\mathrm{HCl}$.

\section{Bulgaria}

\section{Lake Blatniza Series I}

Sediment and mollusk shells from Lagoon-lake Blatniza $(+4 \mathrm{~m}), \mathrm{E}$ shore of Black Sea, NE Bulgaria ( $\left.43^{\circ} 15^{\prime} 04^{\prime \prime} \mathrm{N}, 28^{\circ} 23^{\prime} 02^{\prime \prime} \mathrm{E}\right)$. Coll Aug 1982 by E Bozilova, Biol Fac, Univ Sofia; subm by B Berglund. Dating is part of palaeoecol study belonging to IGCP Sub-proj 158B (Berglund, 1979). Depths refer to sediment surface. 
Lu-2241. Lake Blatniza, 320 to $340 \mathrm{~cm}$

$$
4020 \pm 60
$$

Detritus gyttja rich in shells of small mollusks. Sample aggregated from 3 core pieces, diam ca $2.5 \mathrm{~cm}$, from same level. Comment: mollusk shells and other carbonates, if present, were completely removed by $\mathrm{HCl}$ pretreatment.

Lu-2242. Lake Blatniza, 340 to $360 \mathrm{~cm}$

$4090 \pm 60$

Peaty gyttja with some small mollusk shells. Sample aggregated from 2 core pieces, diam ca $2.5 \mathrm{~cm}$, from same level. Comment: pretreated with $\mathrm{HCl}$ in same way as Lu-2241, above.

Lu-2243. Lake Blatniza, 260 to $280 \mathrm{~cm}$

$4580 \pm 60$

Small mollusk shells (mostly Cardium edule) separated from sandy peat (Phragmites, Cyperaceae, Calystegia) rich in shells. Comment: outer $30 \% 0$ of shells removed by acid leaching.

\section{Lu-2244. Lake Blatniza, 480 to $500 \mathrm{~cm}$}

$5300 \pm 60$

$\delta^{13} C=-25.7 \%$

Clay gyttja with small mollusk shells. Comment: sample pretreated with $\mathrm{HCl}$ in same way as Lu-2241, above.

\section{Tunisia}

\section{Bahiret El Biban series}

Oolites from deposits near beach at Bahiret El Biban, Tunisia $\left(33^{\circ} 18^{\prime}\right.$ N, $11^{\circ} 07^{\prime}$ E). Coll Oct 1983 and subm by A Strasser, Dept Geol, Univ Geneva, Switzerland. Dated to determine if oolites were formed in situ or were reworked from older sediments. No pretreatment.

Lu-2280. Tunisia T 47

$4760 \pm 60$

Oolites from shallow sub-tidal deposit, $150 \mathrm{~m}$ from beach.

\section{Lu-2281. Tunisia T 78}

$4750 \pm 60$

Oolites from ancient coastal dune, $120 \mathrm{~m}$ from beach.

\section{Canada}

\section{Lu-2335. Farrent Island}

$1820 \pm 50$

$\delta^{13} \mathrm{C}=-25.2 \%$

Basal wood (Thuja plicata or Chamaecyperis nootkatensis, id by $\mathrm{N}$ Malmer) from sloping fen on Farrent I., $110 \mathrm{~km}$ SSE of Prince Rupert, British Columbia $\left(53^{\circ} 22^{\prime} \mathrm{N}, 129^{\circ} 25^{\prime} \mathrm{W}\right)$. Sample in contact with mineral soil at base of peat layer, depth $85 \mathrm{~cm}$, exposed by erosion and mainly consisting of 
highly humified Sphagnum peat. Coll July 1983 and subm by N Malmer, Dept Plant Ecol, Univ Lund. Pretreated with $\mathrm{HCl}$ and $\mathrm{NaOH}$.

\author{
ARCHAEOLOGIC SAMPLES
}

Sweden

\title{
Skateholm Series IV
}

Charcoal and sediment from settlement area (Erteb $\phi$ lle culture) at Ska-

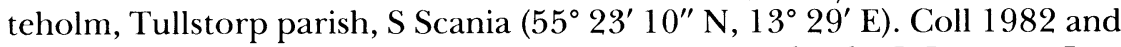
1983 by L Larsson, H Göransson, and T Persson; subm by L Larsson, Inst Archaeol, Univ Lund, and H Göransson. Dated as complement to Skateholm Series I, II, and III (R, 1982, v 24, p 205-206; 1983, v 25, p 887; 1984, v 26, p 405-406).

\section{Lu-2229. Skateholm I, Anl 98 and 100}

$5640 \pm 60$

Charcoal from Structures 98 and 100 , assoc with flint implements. Comment: mild pretreatment with $\mathrm{NaOH}$ and $\mathrm{HCl}$.

Lu-2347. Skateholm I, Grave 43

$$
\begin{array}{r}
\mathbf{6 1 8 0} \pm \mathbf{7 0} \\
\delta^{13} C=-25.1 \% 0
\end{array}
$$

Charcoal from Grave 43 (Larsson, 1983; 1984, p 13, fig 6). Comment: normal pretreatment with $\mathrm{HCl}$ and $\mathrm{NaOH}$.

\section{Lu-2349. Skateholm, P 1, insoluble \\ $\delta^{13} C=-27.2 \%$}

$\mathbf{5 7 6 0} \pm \mathbf{7 0}$

Gyttja from level 122.25 to $125.75 \mathrm{~cm}$ in trench for pollen sampling, $38 \mathrm{~cm}$ below base of transgression deposits (Järavallen). For information about earlier studies of deposits below Järavallen at Skateholm, see Nilsson (1935, p 453-455, Pl VI:22). Comment: pretreated with $\mathrm{HCl}$ and $\mathrm{NaOH}$.

\section{Lu-2349A. P 1, soluble}

$$
5500 \pm 60
$$

Acid-precipitated part of $\mathrm{NaOH}$-soluble fraction from $\mathrm{Lu}-2349$.

\section{Lu-2350. Skateholm, P 2}

$\mathbf{2 9 6 0} \pm \mathbf{5 0}$

Peaty gyttja from level 84 to $87 \mathrm{~cm}$, overlain by transgression deposits, in trench for pollen sampling. Comment: pretreated with $\mathrm{HCl}$ and $\mathrm{NaOH}$. Sample probably contaminated by recent root material.

\section{Östra Vemmenhög series}

Charcoal, wood, and bone from settlement area (Early/Middle Neolithic culture) at Ö Vemmenhög 7:20, Ö Vemmenhög parish, S Scania $\left(55^{\circ}\right.$ $23^{\prime} 30^{\prime \prime} \mathrm{N}, 13^{\circ} 29^{\prime} 20^{\prime \prime}$ E). Coll Sept 1983 and subm by L Larsson. Excavation is part of Skateholm Proj (Larsson, 1983; 1984, p 7 fig 2, and p 36). 
Lu-2346. Ö Vemmenhög 7:20, Sample A $4940 \pm 60$

Charcoal (Corylus avellana) id by $\mathrm{T}$ Bartholin, from cultural layer. Assoc flint artifacts indicate Early Neolithic Period C or Middle Neolithic Period I. Comment: pretreated with $\mathrm{HCl}$ and $\mathrm{NaOH}$.

\section{Lu-2348. Ö Vemmenhög 7:20, Sample B}

$4730 \pm 70$

Charcoal from cultural layer; same artifact assemblage as above. Com ment: pretreated with $\mathrm{HCl}$ and $\mathrm{NaOH}$. Sample undersized; diluted; $80 \%$ sample.

\section{Lu-2351. Ö Vemmenhög 7:20, wood}

$$
\begin{array}{r}
\mathbf{2 9 3 0} \pm \mathbf{5 0} \\
\delta^{13} C=-27.3 \%
\end{array}
$$

Wood from Structure A below cultural layer, assoc with funnel beaker indicating same archaeol period as for Sample A, above. Comment: no explanation for young age. Pretreated with $\mathrm{HCl}$.

\section{Lu-2352. Ö Vemmenhög 7:20, bone}

Collagen from ill-preserved cattle bone, id by L Jonsson, from cultural layer, Sqs $\mathrm{x}=101, \mathrm{y}=107 ; \mathrm{x}=102, \mathrm{y}=108 ; \mathrm{x}=106, \mathrm{y}=107$. Assoc with funnel beaker pottery indicating same archaeol period as for Sample A, above. Comment: organic carbon content: $1.6 \%$. Collagen extracted as described previously (R, 1976, v 18, p 290) with $\mathrm{NaOH}$ treatment. Sample undersized; diluted; $88 \%$ sample.

\section{Lu-2345. Hylliekroken}

$4360 \pm 80$

Collagen from ill-preserved human bone, id by $\mathrm{N}-\mathrm{G}$ Gejvall, possibly from grave structure at Hylliekroken, S Scania $\left(55^{\circ} 35.5^{\prime} \mathrm{N}, 12^{\circ} 55^{\prime} \mathrm{E}\right)$. Coll 1944; subm by L Larsson. Assoc with Late Mesolithic or perhaps Neolithic material (Kalling, 1944; Hjortsjö, 1945). Comment: organic carbon content: $1.6 \%$. Collagen extracted as described previously (R, 1976, v 18, p 290) without $\mathrm{NaOH}$ treatment. Sample undersized; diluted; $64 \% 0$ sample.

\section{St Köpinge Series I}

Charcoal from various sites in St Köpinge parish, S Scania. Archaeol study is part of interdisciplinary proj on dynamics of human influence on landscape in Ystad area. Preliminary excavation previously reported (Tesch 1979a, 1979b; Tesch, Widholm \& Wihlborg, 1980). Coll 1973-1983 and subm by S Tesch, Inst Archaeol, Univ Lund. Charcoal id by T Bartholin, Dept Quaternary Geol, Univ Lund.

\section{Lu-2232. Köpinge 58:1, A49, F99}

$$
\begin{array}{r}
\mathbf{2 7 8 0} \pm \mathbf{5 0} \\
\delta^{13} C=-26.2 \% 0
\end{array}
$$

Charcoal (Quercus sp) from fire pit (grave), Ancient Remain No. 38, at Köpinge 58:1 (55 $\left.28^{\prime} \mathrm{N}, 13^{\circ} 59^{\prime} \mathrm{E}\right)$. Coll 1973-1974. Comment: pretreated with $\mathrm{HCl}$ and $\mathrm{NaOH}$. 
Lu-2248. Köpinge 58:1, A19, F49

$\mathbf{2 8 4 0} \pm \mathbf{5 0}$

Charcoal from fire pit (grave) at same site as Lu-2232, above. Coll 1973-1974. Comment: mild pretreatment with $\mathrm{NaOH}$ and $\mathrm{HCl}$.

Lu-2252. Köpinge 58:1, A44, F87

$\mathbf{2 7 7 0} \pm \mathbf{5 0}$

$\delta^{13} C=-26.5 \%$

Charcoal (Quercus sp) from fire pit (grave) at same site as Lu-2232. Coll 1973-1974. Comment: pretreated with $\mathrm{HCl}$ and $\mathrm{NaOH}$.

Lu-2257. Köpinge 58:1, A8, F9

$\mathbf{2 6 9 0} \pm \mathbf{5 0}$

$\delta^{13} C=-25.0 \%$

Charcoal (Fraxinus excelsior, Tilia sp) from fire pit (grave) at same site as Lu-2232. Coll 1973-1974. Comment: mild pretreatment with $\mathrm{NaOH}$ and HCl.

Lu-2260. Köpinge 58:1, A9, F10

$\mathbf{2 6 8 0} \pm \mathbf{5 0}$

$\delta^{13} \mathrm{C}=-25.8 \%$

Charcoal (Quercus sp) from fire pit (grave) at same site as Lu-2232. Coll 1973-1974. Comment: pretreated with $\mathrm{HCl}$ and $\mathrm{NaOH}$.

\section{Lu-2234. Köpinge 64:1, A277}

$1630 \pm 50$

Charcoal (Fraxinus excelsior, Quercus sp, Pomoideae) from hearth with brittle-burned stones and soot, at Köpinge $64: 1$ ( $\left.55^{\circ} 26^{\prime} \mathrm{N}, 13^{\circ} 59^{\prime} \mathrm{E}\right)$. Coll 1980. Comment: mild pretreatment with $\mathrm{NaOH}$ and $\mathrm{HCl}$.

Lu-2250. Köpinge 15:22, A167

$1790 \pm 60$

Charcoal from stem wood (Quercus sp) from post holes of Iron age house at Köpinge 15:22 (55 $\left.26^{\prime} \mathrm{N}, 13^{\circ} 59^{\prime} \mathrm{E}\right)$. Coll 1979. Comment: no pretreatment; sample undersized; diluted; 80\% sample.

\section{Lu-2249. Köpinge 19:85, A6}

$\mathbf{2 4 5 0} \pm \mathbf{5 0}$

Charcoal (Corylus avellana, Fraxinus excelsior) from hearth with brittleburned stones and soot at Köpinge 19:85 (55 26 $\left.6^{\prime} \mathrm{N}, 13^{\circ} 59^{\prime} \mathrm{E}\right)$. Coll 1981. Comment: pretreated with $\mathrm{HCl}$ and $\mathrm{NaOH}$.

\section{Lu-2259. Köpinge 19:85, A2}

$\mathbf{2 6 0 0} \pm \mathbf{5 0}$

Charcoal (Alnus sp, Fraxinus excelsior) from hearth with brittle-burned stones and soot at same site as Lu-2249, above. Coll 1981. Comment: pretreated with $\mathrm{HCl}$ and $\mathrm{NaOH}$. 
Lu-2233. Köpinge, Väg 10, A64

$\mathbf{2 0 7 0} \pm \mathbf{5 0}$

$\delta^{13} C=-23.2^{\circ} \% 0$

Charcoal (Acer sp, Corylus avellana) from hearth with brittle-burned

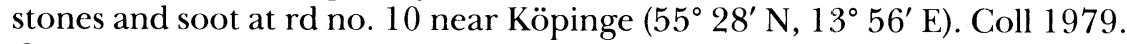
Comment: pretreated with $\mathrm{HCl}$ and $\mathrm{NaOH}$.

Lu-2255. Kabusa, Väg 10, A1

$\mathbf{1 7 3 0} \pm \mathbf{5 0}$

Charcoal (Tilia sp, Alnus sp, Corylus avellana) from hearth with britteburned stones and soot at $\mathrm{rd}$ no. 10 near Kabusa $\left(55^{\circ} 26^{\prime} \mathrm{N}, 13^{\circ} 58^{\prime} \mathrm{E}\right)$. Coll 1980. Comment: mild pretreatment with $\mathrm{NaOH}$ and $\mathrm{HCl}$.

Lu-2231. L:a Köpinge 14:43, A192

$\mathbf{2 7 4 0} \pm \mathbf{5 0}$

$\delta^{13} C=-27.6 \%$

Charcoal (Alnus sp) from base of hearth pit at L:a Köpinge 14:43 $\left(55^{\circ}\right.$ $26^{\prime} \mathrm{N}, 13^{\circ} 56^{\prime} \mathrm{E}$ ). Coll 1979. Comment: pretreated with $\mathrm{HCl}$ and $\mathrm{NaOH}$.

Lu-2256. L:a Köpinge 14:43, A484

$2670 \pm 60$

$\delta^{13} C=-26.6 \%$

Charcoal from stem wood (Alnus sp) from post hole at same site as Lu2231, above. Coll 1979. Comment: mild pretreatment with $\mathrm{NaOH}$ and $\mathrm{HCl}$. Sample undersized; diluted; $87 \%$ sample.

Lu-2235. L:a Köpinge 19:1, A550

$1650 \pm 50$

$\delta^{13} C=-26.3 \%$

Charcoal (Betula sp) from pit house at L:a Köpinge 19:1 $\left(55^{\circ} 26^{\prime} \mathrm{N}, 13^{\circ}\right.$ $56^{\prime}$ E). Coll 1979. Comment: pretreated with $\mathrm{HCl}$ and $\mathrm{NaOH}$.

Lu-2251. L:a Köpinge 6:20, A324, F50

$\mathbf{2 0 0 0} \pm \mathbf{5 0}$

$\delta^{13} \mathrm{C}=-27.0^{\%} \%$

Charcoal (Quercus sp) from hearth with brittle-burned stones and soot at L:a Köpinge 6:20 (55 $\left.28^{\prime} \mathrm{N}, 13^{\circ} 59^{\prime} \mathrm{E}\right)$. Coll 1975. Comment: pretreated with $\mathrm{HCl}$ and $\mathrm{NaOH}$.

\section{Lu-2258. Kabusafältet, $\mathbf{P 1}, \mathbf{A 2}$}

$1600 \pm 45$

Charcoal (Quercus sp, Corylus avellana) from hearth with brittleburned stones and soot below $>1 \mathrm{~m}$ aeolian sand on Kabusa field $\left(55^{\circ} 25^{\prime} \mathrm{N}\right.$, $\left.14^{\circ} 00^{\prime} \mathrm{E}\right)$. Coll 1983. Comment: pretreated with $\mathrm{HCl}$ and $\mathrm{NaOH}$.

\section{Hagestad series}

Charcoal from various sites in Hagestad area, Löderup parish, S Scania. Coll 1963-1966 and subm by M Strömberg, Inst Archaeol, Univ Lund. Dating is part of interdisciplinary proj in SE Scania centered around Hagestad (Strömberg, 1980, 1982, 1984). For other dates from Hagestad, see R, 1972, v 14, p 394-395; 1973, v 15, p 509; 1974, v 16, p 324; 1975, v 17, p 191-192; 1976, v 18, p 313. 
Lu-2230. Hagestad 40:5, Sample 1:83

$\mathbf{2 0 9 0} \pm \mathbf{5 0}$

$\delta^{13} C=-24.9 \%$

Charcoal from Hearth no. 1 on field with Middle Neolithic hut base and Late Neolithic graves at Hagestad 40:5 (55 $\left.24^{\prime} \mathrm{N}, 14^{\circ} 09^{\prime} \mathrm{E}\right)$. Assoc with flint and pottery indicating Middle Neolithic culture. Comment: pretreated with $\mathrm{HCl}$ and $\mathrm{NaOH}$.

Lu-2261. Hagestad 24:1, Sample 2:83

$1180 \pm 45$

$\delta^{13} \mathrm{C}=-25.6 \%$

Charcoal from W pit in $\operatorname{Tr} 1$ at Hagestad 24:1 (55 $\left.25^{\prime} \mathrm{N}, 14^{\circ} 09^{\prime} \mathrm{E}\right)$. Assoc with slag, flint, and wattle and daub, indicating Late Iron age. Comment: pretreated with $\mathrm{HCl}$ and $\mathrm{NaOH}$.

Lu-2262. Hagestad 22:8, Sample 3:83

$4070 \pm 60$

$\delta^{13} \mathrm{C}=-25.9 \%$

Charcoal from test pit at Hagestad 22:8 $\left(55^{\circ} 24^{\prime} \mathrm{N}, 14^{\circ} 11^{\prime} \mathrm{E}\right)$. Assoc with flint and pottery indicating Middle Neolithic culture. Comment: pretreated with $\mathrm{HCl}$ and $\mathrm{NaOH}$.

\section{Lu-2263. Hagestad 43:5A, Sample 4:83}

$1800 \pm \mathbf{5 0}$

Charcoal from cultural layer in Tr no. 1 at Hagestad $43.5 \mathrm{~A}\left(55^{\circ} 24^{\prime} \mathrm{N}\right.$ $\left.14^{\circ} 08^{\prime} \mathrm{E}\right)$. Assoc with flint and pottery indicating Middle Neolithic culture. Comment: mild pretreatment with $\mathrm{NaOH}$ and HCl. General Comment: Lu2261 and -2262 agree with archaeol estimate based on assoc artifacts. Lu2230 and -2263 unexpectedly late for unknown reason.

\section{Gislöv series}

Charcoal from settlement area at Gislöv 2, Ö Nöbbelöv parish, Scania $55^{\circ} 30^{\prime} \mathrm{N}, 14^{\circ} 17^{\prime} \mathrm{E}$ ). Coll 1983-1984 and subm by M Strömberg. For other dates from Gislöv, see R, 1980, v 22, p 1062; 1982, v 24, p 207-208. All samples pretreated with $\mathrm{HCl}$ and $\mathrm{NaOH}$.

\section{Lu-2328. Gislöv 2, Sample 1:HT83}

$1480 \pm 50$

Charcoal from hearth, $1 \mathrm{~m}$ below present ground surfa in hearth but pottery and iron objects above it.

\section{Lu-2329. Gislöv 2, Sample 2:HT83}

$650 \pm 45$

$$
\delta^{13} \mathrm{C}=-25.7 \%
$$

Charcoal from coal pit in upper cultural layer, Sq 18 (prelim no.). Assoc with pottery and iron objects indicating Early Medieval time. Comment: somewhat later than expected, but reasonable.

\section{Lu-2330. Gislöv 2, Sample 3:HT83}

$660 \pm 45$

Charcoal from coal pit below hearth in upper cultural layer. Assoc with pottery and iron objects. Expected to be from same period as Lu-2329, above. 
Lu-2331. Gislöv 2, Sample 1:VT84

$$
\begin{array}{r}
\mathbf{2 0 5 0} \pm \mathbf{5 0} \\
\delta^{13} C=-24.7 \% 0
\end{array}
$$

Charcoal from Grave 1 (cremation). Assoc with pottery indicating Roman Iron age. Comment: somewhat earlier than expected.

\section{Fotevik Series III}

Wood and moss caulking and wood from poles, assoc with Late Viking age stone blocking in entrance to Foteviken Bay, SW Scania $\left(55^{\circ} 28^{\prime} \mathrm{N}, 12^{\circ}\right.$ $56^{\prime}$ E). Coll May 1982 by Malmö Sjöfartsmus, Malmö; subm by C IngelmanSundberg and P Söderhielm, Malmö Sjöfartsmus. Repts pub previously (Ingelman-Sundberg \& Söderhielm, 1982; Crumlin-Pedersen, 1984). For other dates from Fotevik, see R, 1983, v 25, p 888; 1984, v 26, p 408409.

\section{Lu-2240. Fotevik, F82.V4.2}

$1110 \pm 45$

Wood from Board 2 , Wreck 4 (Crumlin-Pedersen, 19 41, p 47). Comment: pretreated with $\mathrm{HCl}$ and $\mathrm{NaOH}$.

Lu-2320. Fotevik, F82.V1

$$
\begin{array}{r}
1060 \pm \mathbf{6 0} \\
\delta^{13} C=-27.2 \% 0
\end{array}
$$

Brown-moss caulking from scarf-joint of keel, Wreck 1 (Crumlin-Pedersen, 1984, p 28-40). Comment: only HCl pretreatment; sample undersized; diluted; 57\% sample. Fibrous caulking material (sheep's wool) from same wreck dated at $1030 \pm 45 \mathrm{BP}(\mathrm{Lu}-2213: \mathrm{R}, 1984$, v 26, p 409).

\section{Lu-2321. Fotevik, F82.V2.1}

$1080 \pm 45$

Wood from Board 1, Wreck 2 (Crumlin-Pedersen, 1984, p 40-43; fig 36, p 43). Comment: pretreated with $\mathrm{NaOH}$ and $\mathrm{HCl}$.

Lu-2322. Fotevik, F82.V5.6

$$
\delta^{13} C=\begin{array}{r}
\mathbf{9 6 0} \pm \mathbf{4 5} \\
-27.5 \% 0
\end{array}
$$

Oak wood from Boat Rib 6, Wreck 5 (Crumlin-Pedersen, 1984, p 4649; fig 43-44, p 49). Comment: pretreated with $\mathrm{HCl}$ and $\mathrm{NaOH}$.

\section{Lu-2323. Fotevik, Pole ARN}

$1000 \pm 45$

Wood from Pole ARN, X105751.300; Y13589.196. Comment: pretreated with $\mathrm{HCl}$ and $\mathrm{NaOH}$.

\section{Lu-2324. Fotevik, Pole AFE}

$1030 \pm 45$

Wood from Pole AFE, F82.S50, X105480.083; Y13694.621. Comment: pretreated with $\mathrm{HCl}$ and $\mathrm{NaOH}$.

\section{Lu-2325. Fotevik, Pole AHT}

$$
950 \pm \mathbf{4 5}
$$

Wood from Pole AHT, F82.S58, X105448.652; Y13694.803. Comment: pretreated with $\mathrm{HCl}$ and $\mathrm{NaOH}$. 
Lu-2326. Fotevik, Pole AFS

Wood from Pole AFS, F82 S30, X105448.652; Y13694.803 (Ingetman-Sundberg \& Söderhielm, 1982, p 20, fig 16). Comment: pretreated with $\mathrm{HCl}$ and $\mathrm{NaOH}$.

\section{Lu-2327. Masmo}

$$
\begin{array}{r}
4420 \pm 60 \\
\delta^{13} C=-25.6 \% 0
\end{array}
$$

Food remains from cooking vessels from site with Neolithic, Bronze age, and Iron age artifacts at Masmo, Södermanland $\left(59^{\circ} 14.5^{\prime} \mathrm{N}, 17^{\circ} 53^{\prime}\right.$ E). Assoc with pottery and quartz artifacts indicating Neolithic or PreRoman Iron age. Coll April 1984 and subm by B Hulthén, Lab for Ceramic and Clay Mineralogy, Dept Quaternary Geol, Univ Lund. No pretreatment.

\section{Lu-2226. Åbyn, Byske}

$770 \pm 45$

$$
\delta^{13} C=-25.3 \% \text { o }
$$

Wood from dugout canoe (No. SM1268) from swamp N of Åbyn, Byske, Skellefteå, N Sweden $\left(65^{\circ} 03^{\prime} \mathrm{N}, 20^{\circ} 21^{\prime} \mathrm{E}\right)$. Coll 1981 by workers during drainage of swamp; subm by P Gustafsson, Skellefteå Mus, Skellefteå. Assoc with small paddle ornamented with circles and points. Comment: pretreated with $\mathrm{HCl}$ and $\mathrm{NaOH}$.

\section{Lu-2227. Västra Lillträsket, Nyland}

$730 \pm 45$

Wood from dugout canoe (No. SM6552) from shore of Lake Västra

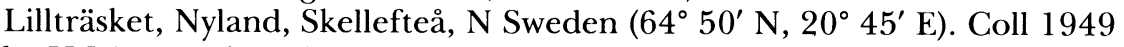
by $\mathrm{H}$ Wagnstedt and $\mathrm{E}$ Westerlund; subm by $\mathrm{P}$ Gustafsson. Comment: sample delignified and residue washed repeatedly to remove traces of preservative as completely as possible. "Cellulose" charred in nitrogen atmosphere before burning.

\section{Lu-2228. Skellefteå, Alces alces}

$\mathbf{8 6 1 0} \pm 90$ from dark blue clay $2.4 \mathrm{~m}$ below $\left.45^{\prime} \mathrm{N}, 20^{\circ} 57^{\prime} \mathrm{F}\right)$. Coll 1944 by T Eke, town of Skelleftea, N Sweden $\left(64^{\circ}\right.$ Gustafsson. Diatom and pollen analysis indicate age of ca $7000 \mathrm{yr}$ (Ekblom, 1946). Comment: organic carbon content: 3\%. Collagen extracted as described previously (R, 1976, v 18, p 290). Sample undersized; diluted; $67-$ $\%$ sample. (3 1-day counts.)

\section{Kyrkudden series (II)}

Charcoal from excavation of medieval site at Kyrkudden, Hietaniemi parish, Norrbotten $\left(66^{\circ} 13^{\prime} \mathrm{N}, 23^{\circ} 43^{\prime} \mathrm{E}\right)$. Coll 1979 and subm by $\mathrm{T}$ Wallerström, Norrbottens Mus, Luleå. For other dates from Kyrkudden, see R, 1984, v 26, p 404-405. No pretreatment; small samples. 
Lu-2286. Kyrkudden, F2055, F2043, F2268

$530 \pm 45$

Charcoal (Pinus sp) from cultural layer near blacksmith's workshop.

\section{Lu-2287. Kyrkudden, F2196, F2247, F2251}

$\mathbf{4 7 0} \pm \mathbf{4 5}$

Charcoal (Pinus sp) from cultural layer, coll close to Lu-2286, above.

\section{Ireland}

\section{Lu-2225. Carrowmore, Culleenamore 15A \\ $2980 \pm 60$ \\ $\delta^{13} C=-25.7 \%$}

Charcoal Sample 1:82 from lower layer in outer kitchen midden (15A) at Settlement 15, Culleenamore, Co Sligo (54 $16^{\circ} \mathrm{N}, 8^{\circ} 36^{\prime} \mathrm{W}$ ). Coll 1982 and subm by G Burenhult, Inst Archaeol, Univ Stockholm. Results of excavations 1980 and 1981 at Settlement 15 previously pub (Österholm \& Österholm, 1984). Samples coll 1980 above sand at base of midden (C14:18) and ca $1.5 \mathrm{~m}$ above base (C14:6) dated at $4710 \pm 100 \mathrm{BP}$ (St-7624) and $3780 \pm 60$ BP (Lu-1 759: R, 1981, v 23, p 401). Sample C14:30 coll 1981 in lower part of midden (Burenhult, 1984, p 344, fig 240) dated at $3970 \pm 75$ вP (Lu-1948: R, 1982, v 24, p 211$)$. Dates from hearths in other parts of midden are $3060 \pm 100 \mathrm{BP}$ (Fra-60) and $3045 \pm 100 \mathrm{BP}$ (Fra-65) (Burenhult, 1984, p 131).

\section{Lu-2239. Carrowkeel, 336 to $342 \mathrm{~cm}$}

$$
\begin{array}{r}
\mathbf{4 2 5 0} \pm \mathbf{6 0} \\
\delta^{13} C=-28.8 \%
\end{array}
$$

Highly humified fen peat from bog in Treanscrabbagh Valley, $\mathrm{N}$ of Cairn B and WNW of Cairn C and D of Carrowkeel megalithic cemetery (Göransson, 1984, p 165-168), Bricklieve Mts, Co Sligo (54 ${ }^{\circ} 03^{\prime} \mathrm{N}, 8^{\circ} 23^{\prime}$ W). Coll Aug 1981 by H Göransson, M Thelaus, and M A Timoney; subm by H Göransson and G Burenhult. Pollen analysis by H Göransson (1984, p 184-185). For other dates from Carrowkeel, see R, 1983, v 25, p 889. Sample dates early part of forest regeneration phase (Göransson, 1984, p 188).

\section{Carrowmore Strandhill series}

Stratified sandy terrestrial submerged peat (Göransson, 1984, p 168170) from deposit exposed during low tide ca $500 \mathrm{~m} \mathrm{~N}$ of Strandhill, Knocknarea peninsula, ca $6 \mathrm{~km}$ WNW of Carrowmore megalithic cemetery, Co Sligo $\left(54^{\circ} 16^{\prime} \mathrm{N}, 8^{\circ} 36^{\prime} \mathrm{W}\right)$. Coll 1983 and subm by G Burenhult and $\mathrm{H}$ Göransson. Peat from same site coll 1981 dated at $5220 \pm 60$ BP (Lu-2021: $\mathrm{R}, 1983$, v 25, p 890). Site described and results discussed by Burenhult (1984, p 38-42). Pretreated with $\mathrm{HCl}$ and $\mathrm{NaOH}$.

\section{Lu-2223. Carrowmore, Strandhill I:1983}

$$
\begin{array}{r}
\mathbf{5 6 8 0} \pm \mathbf{6 0} \\
\delta^{13} C=-26.1 \% 0
\end{array}
$$

Basal $4 \mathrm{~cm}$ of peat layer, $9 \mathrm{~cm}$ thick. Highly humified sandy-silty peat with rootlets of Carex. 


\section{Lu-2224. Carrowmore, Strandhill II:1983}

Uppermost $5 \mathrm{~cm}$ of peat layer, sample rich in Phragmites and Carex rootlets. Root epidermis of Eriophorum present. Initial decrease of Ulmus pollen percentage in pollen spectrum from top of peat. Pollen analysis by $\mathrm{H}$ Göransson (1984, p 186-187).

\section{REFERENCES}

Berglund, B E, 1979, Presentation of the IGCP Project 158 B Palaeohydrological changes in the temperate zone in the last 15000 years-Lake and mire environments: Acta Univ Ouluensis, Ser A, No. 82, Geol No. 3, p 39-48.

Björck, S, 1979, Late Weichselian stratigraphy of Blekinge, SE Sweden, and water level changes in the Baltic Ice Lake: Thesis 7, Dept Quaternary Geol, Univ Lund, 248 p.

1981, A stratigraphic study of Late Weichselian deglaciation, shore displacement and vegetation history in south-eastern Sweden: Fossils \& Strata (Oslo), no. 14, 93 p.

Burenhult, Göran, 1984, The archacology of Carrowmore. Environmental archaeology and the Megalithic tradition at Carrowmore, Co Sligo, Ireland: Theses and papers in NorthEuropean Archaeol 14, Inst Archaeol, Univ Stockholm, 396 p.

Crumlin-Pedersen, Ole, 1984, Fotevik. De marinarkaeologiske undersögelser 1981 og 1982 in Pugna Forensis_-? Arkeologiska undersökningar kring Foteviken, Skåne 1981-1983, Länsstyrelsen i Malmöhus län, p 7-68.

Ekblom, Tore, 1946, Ett fynd av subfossil älg i Skellefteå: Fauna och Flora, 1946, p 251255

Firbas, F, 1949, Spät- und nacheiszeitliche Waldgeschichte Mitteleuropas nördlich der Alpen I: Jena, Fischer Verlag, $480 \mathrm{p}$.

Göransson, H, 1977, The Flandrian vegetational history of southern Östergötland: Thesis 3, Dept Quaternary Geol, Univ Lund, V + 147 p.

1984, Pollen analytical investigations in the Sligo area, in Burenhult, Göran 1984, The archaeology of Carrowmore. Environmental archaeology and the Megalithic tradition at Carrowmore, Co Sligo, Ireland: Theses and papers in North-European Archaeol 14, Inst Archaeol, Univ Stockholm, p 154-193.

Håkansson, Sören, 1980, University of Lund radiocarbon dates XIII: Radiocarbon, v 22, p $1045-1063$

403 . 213.

891

891.

1982, University of Lund radiocarbon dates XV: Radiocarbon, v 24, p 194

1983a, University of Lund radiocarbon dates XVI: Radiocarbon, v 25, p 875-

1983b, A reservoir age for the coastal waters of Iceland: Geol Fören Stockholm Förh, v 105, p 65-68.

411 - 1984, University of Lund radiocarbon dates XVII: Radiocarbon, v 26, p 392

Hillefors, Åke, 1969, Västsveriges glaciala historia och morfologi (with English summary): Lunds Univ Geog Inst Medd, Avh 60, 319 p.

Hjortsjö, C-H, 1945, Le crâne de Hylliekroken de l'age de pierre nordique ancien, l'époque Ertebölle. Etude d'anthropologie: Acta Archaeologica, v 16, p 222-229.

Ingelman-Sundberg, Catharina and Söderhielm, Per, 1982, Vikingaskepp Foteviken. Marinarkeologisk undersökning i Foteviken, Skånc. Preliminär rapport, Okt 82: Malmö Sjöfartsmus, $26 \mathrm{p}+3$ app.

Kalling S, 1944, Ett strandfynd från äldre stenåldern i Hylliekroken: Malmö Fornminnesfören Årsskr 1944, p 76-85.

Larsson, Lars, 1983, Skateholmsprojektet. Jägare-fiskare-bönder: Limhamniana (Malmö) $1983, \mathrm{p} 7-40$.

1984, The Skateholm Project. A Late Mesolithic settlement and cemetery comp 5-38.

Mangerud, J, Andersen, S T, Berglund, B E, and Donner, J J, 1974, Quaternary stratigraphy of Norden, a proposal for terminology and classification: Boreas (Oslo), v 3, p 109-126.

Nilsson, Tage, 1935, Die pollenanalytische Zonen-gliederung der spät- und postglazialen Bildungen Schonens: Geol Fören Stockholm Förh, v 57, p 385-562.

Österholm, Inger and Österholm, Sven, 1984, The kitchen middens along the coast of Bally- 
sadare Bay, in Burenhult, Göran, The archaeology of Carrowmore. Environmental archaeology and the Megalithic tradition at Carrowmore, Co Sligo, Ireland: Theses and papers in North-European Archaeol 14, Inst Archaeol, Univ Stockholm, p 326-345.

Strömberg, Märta, 1980, The Hagestad investigation-A project analysis: Lunds Univ Hist Mus, Medd, 1979-1980, new ser v 3, p 47-60.

- 1982, Specialized, Neolithic flint production with a hoard of scrapers at Hagestad as an example: Lunds Univ Hist Mus, Medd, 1981-1982, new ser v 4, p 48-64.

_ 1984, Burial traditions in Late Neolithic society. Models and results in the Hagestad project: Lunds Univ Hist Mus, Medd, 1983-1984, new ser v 5, p 47-71.

Svensson, Göran, 1965, Vegetationsundersökningar på Store mosse: Bot Notiser (Lund), v 118 , fasc 1, p $49-86$

Tesch, Sten, 1979a, Bronsåldershus i St Köpinge: Ale, Hist Tidsskr för Skåneland, 1979, no. 1, p $27-29$.

1979b, Forntidens bopålar: Ale, Hist Tidsskr för Skåneland, 1979, no. 3, p $1-10$.

Tesch, S, Widholm, D, and Wihlborg, A A, 1980, Forntidens bopålar. Stora Köpingebygden under 5000 år: Riksantikvarieämbetet UV-Syd Skriftserie, no. 1, Lund, 39 p. 